\title{
Aseptic inflammation of prosthetic knee in a patient affected by rheumatoid arthritis
}

\author{
Michele Maria Luchetti, Devis Benfaremo, Matteo Rossini, Armando Gabrielli
}

Dipartimento Scienze Cliniche e Molecolari, Università Politecnica delle Marche, Ancona, Italy

\section{Correspondence to} Dr Michele Maria Luchetti, m.luchetti@univpm.it

Accepted 18 November 2016

\section{DESCRIPTION}

A woman aged 40 years affected by an aggressive and active form of rheumatoid arthritis (RA) underwent total knee arthroplasty (TKA) of the left knee for persistent synovitis after several therapeutic lines, the last one included methotrexate and a TNF-inhibitor.

Two months after the surgical procedure, the patient reported mild fever and persistent swelling of the left knee. On examination, there were signs of inflammation but no effusion to drain. Ultrasonography only showed oedema of the tissues surrounding the knee, and therefore, suspecting a prosthetic infection, antibiotic therapy was immediately started.

A subsequent scintigraphy with $99 \mathrm{mTC}-\mathrm{HmPAO}$ (hexamethylpropylene-amine-oxime)-labelled leucocytes demonstrated the presence of early and persistent accumulation of labelled leucocytes in the femoral and tibial periprosthetic soft tissues, supporting the hypothesis of prosthetic infection (figure 1A).
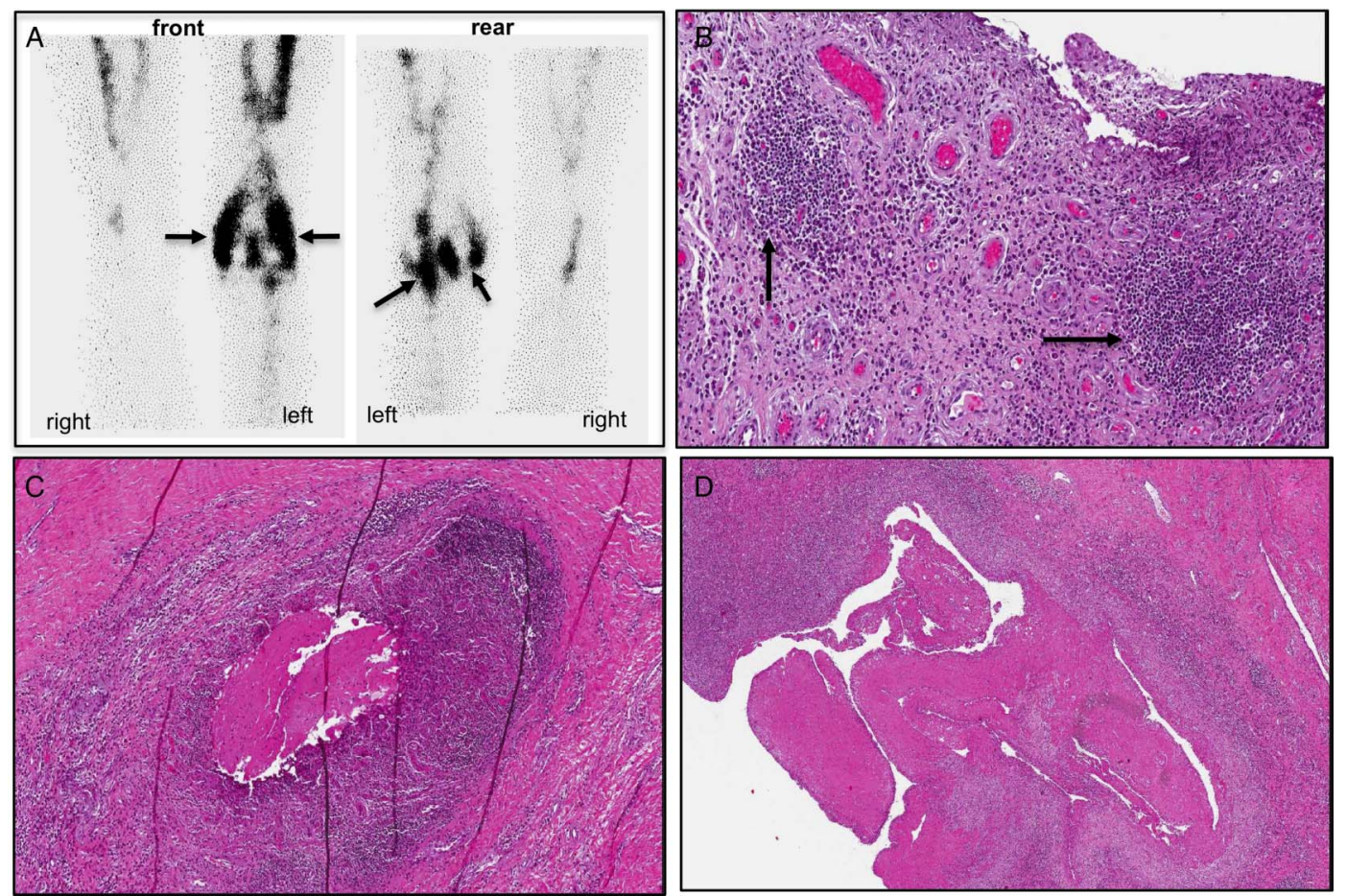

Empiric therapy with different lines of broadspectrum antibiotics was continued for another month without benefit.

A revision surgery of the left knee was therefore performed and the histopathological examination of the surgical specimen demonstrated lymphocytic and plasmacellular infiltration in the periarticular soft tissues and the presence of rheumatoid nodules, without active synovitis (figure 1B-D).

A diagnosis of extra-articular RA recurrence sustained by rheumatoid nodules within the soft tissues surrounding the prosthetic joint was made.

Extra-articular RA recurrence after TKA was previously described and usually presents with rheumatoid nodules, lymphoplasmacytic infiltration and/or proliferation of synovial stromal cells. ${ }^{1}$

Though infection represents the primary suspicion in immunosuppressed patients, especially those taking a TNF-inhibitor, ${ }^{3}$ the possibility of an extra-articular RA recurrence mimicking infection after prosthetic surgery should be considered in the differential diagnosis.
To cite: Luchetti MM, Benfaremo D, Rossini M, et al. BMJ Case Rep Published online: [please include Day Month Year] doi:10.1136/bcr-2016218230

Figure 1 (A) Images of the scintigraphy with 99mTC-HmPAO (hexamethylpropylene-amine-oxime)-labelled leucocytes, showing early and persistent (after 4 hours) accumulation (black arrows) of labelled leucocytes in the femoral and tibial periprosthetic space and in periarticular soft tissues, particularly in the rear of the left knee. (B) The surgical specimen is represented by iuxta-articular fibro-fatty soft tissues infiltrated by plasma cells and lymphocytes, with the presence of lymphoid follicles (black arrows). Rheumatoid nodules are also evident; they are composed of a necrotic centre impregnated with fibrin, surrounded by a predominantly histiocytic inflammatory reaction, often arranged in a palisading fashion (C and D). 


\section{Learning points}

- Immunosuppressive treatment in rheumatoid arthritis (RA) patients raised concern of septic complications in patients undergoing surgery.

- Periprosthetic RA recurrence should be considered in the differential diagnosis of suspected septic arthritis after elective joint surgery.

- Periprosthetic RA recurrence should be accounted like a real RA flare and treated consequently.

Contributors MML and DB have contributed significantly in conception and design, acquisition and interpretation of data, drafting the article and revising the manuscript for important intellectual content. MR contributed in acquisition and interpretation of data. AG contributed in analysis and interpretation of data and revision of the manuscript for important intellectual content. All authors gave final approval of the version to be published.

Competing interests None declared.

\section{Patient consent Obtained.}

Provenance and peer review Not commissioned; externally peer reviewed.

\section{REFERENCES}

1 Inoue K, Nishioka J, Hukuda S, et al. Rheumatoid nodules at the cement-bone interface in revision arthroplasty of rheumatoid patients. J Bone Joint Surg $\mathrm{Br}$ 1993:75:455-8.

2 Fink B, Berger I, Siegmüller $C$, et al. Recurring synovitis as a possible reason for aseptic loosening of knee endoprostheses in patients with rheumatoid arthritis. J Bone Joint Surg Br 2001;83:604-8.

3 Ramiro S, Gaujoux-Viala C, Nam JL, et al. Safety of synthetic and biological DMARDs: a systematic literature review informing the 2013 update of the EULAR recommendations for management of rheumatoid arthritis. Ann Rheum Dis 2014;73:529-35.

Copyright 2016 BMJ Publishing Group. All rights reserved. For permission to reuse any of this content visit

http://group.bmj.com/group/rights-licensing/permissions.

BMJ Case Report Fellows may re-use this article for personal use and teaching without any further permission.

Become a Fellow of BMJ Case Reports today and you can:

- Submit as many cases as you like

- Enjoy fast sympathetic peer review and rapid publication of accepted articles

- Access all the published articles

- Re-use any of the published material for personal use and teaching without further permission

For information on Institutional Fellowships contact consortiasales@bmjgroup.com

Visit casereports.bmj.com for more articles like this and to become a Fellow 